\title{
EXPORTAÇÕES E $O$ DESENVOLVIMENTO REGIONAL: UM BALANÇO DA LEI KANDIR PARA O RIO DE JANEIRO, PARANÁ E MINAS GERAIS*
}

\author{
Recebido: 15 de junho de 2018 - Aprovado: 13 de setembro de 2018 \\ https://doi.org/10.22395/seec.v22n50a9 \\ Robson Dias Da Silva** \\ Gabriela Mello Gonçalves***
}

\section{RESUMO}

\begin{abstract}
O estudo apresenta um dos pontos de mais intenso debate nos estudos regionais da economia brasileira: os efeitos da Lei Kandir sobre a arrecadação tributária de estados produtores de produtos primários destinados ao mercado mundial. O ciclo de alta dos preços internacionais dos produtos básicos, associado à busca de saldos em balança comercial, ensejou um claro processo de reprimarização da economia brasileira e aumentou a dependência de alguns territórios em relação à produção de recursos naturais. Com foco no caso de três estados da federação (Minas Gerais, Rio de Janeiro e Paraná), o estudo mostra as perdas que os três principais produtores de commodities têm tido, do ponto de vista fiscal, por ocasião da Lei Kandir e da busca de maior competitividade nacional nos mercados globais.
\end{abstract}

\section{PALAVRAS-CHAVE}

Economia regional; desenvolvimento; tributação; exportações de produtos primários; Brasil.

\section{CLASSIFICAÇÃO JEL}

\author{
R11, H71, F14
}

\section{CONTEÚDO}

Introdução; 1. Dinâmica econômica e reprimarização das exportações no Brasil; 2. Lei Kandir: histórico e objetivos; 3. As perdas fiscais de Minas Gerais, Paraná e Rio de Janeiro; 4. Conclusões; Bibliografia.

Artigo originado do Projeto de Pesquisa "Desenvolvimento e Crise no Estado do Rio de Janeiro (2000-2020)" e financiado pela Fundação ao Amparo à Pesquisa do Estado do Rio de Janeiro, válido entre 2018 e 2020.

. $\quad$ Economista, Universidade Federal Rural do Rio de Janeiro, Seropédica, Brasil. Mestre em Desenvolvimento Econômico, Universidade Estadual de Campinas, Campinas, Brasil. Doutor em Desenvolvimento Econômico, Universidade Estadual de Campinas, Campinas, Brasil. Professor e pesquisador PPGDT/PPGCTIA, Universidade Federal Rural do Rio de Janeiro, Seropédica, Brasil. E-mail: robsondsilva@gmail.com

*** Economista, Universidade Federal Rural do Rio de Janeiro, Nova Iguaçu, Brasil. E-mail: gabriela.mello95@ gmail.com 


\section{EXPORTACIONES Y DESARROLLO REGIONAL: UN BALANCE DE LA LEY KANDIR PARA RIO DE JANEIRO, PARANÁ Y MINAS GERAIS}

\section{RESUMEN}

El estudio presenta uno de los puntos de más intenso debate en los estudios regionales de la economía brasileña: los efectos de la Ley Kandir sobre el recaudo tributario de estados productores de productos primarios destinados al mercado mundial. El ciclo de alta de los precios internacionales de los productos básicos, asociado a la búsqueda de saldos en balanza comercial, han dado la oportunidad a un claro proceso de reprimarización de la economía brasileña y han aumentado la dependencia de algunos territorios con relación a la producción de recursos naturales. Con enfoque en el caso de tres estados de la federación (Minas Gerais, Rio de Janeiro y Paraná), el estudio muestra las pérdidas que los tres principales productores de commodities han tenido, desde la perspectiva fiscal, por causa de la Ley Kandir y de la búsqueda por más competitividad nacional en los mercados globales.

\section{PALABRAS CLAVE}

Economía regional; desarrollo; tributación; exportaciones de productos primarios; Brasil.

\section{CLASSIFICACIÓN JEL}

R11, H71, F14

\section{CONTENIDO}

Introducción; 1. Dinámica económica y reprimarización de las exportaciones en Brasil; 2. Ley Kandir: histórico y objetivos; 3. Las pérdidas fiscales de Minas Gerais, Paraná y Río de Janeiro; 4. Conclusiones; Bibliografía.

\section{EXPORTS AND REGIONAL DEVELOPMENT: A BALANCE OF THE KANDIR LAW FOR RIO DE JANEIRO, PARANÁ AND MINAS GERAIS}

\section{ABSTRACT}

The study presents one of the most intense debates in the regional studies of the Brazilian economy: the effects of the Kandir law on the tax collection of the producer states of primary products destined for the world market. The high cycle of international prices of essential products, associated with the search for profits in the trade balance, started a clear process of reprimarization of the Brazilian economy and increased the dependence of some territories concerning the production of natural resources. Focusing on the case of three states of the federation (Minas Gerais, Rio de Janeiro, and Paraná), the study shows the losses that the three leading commodities producers have had, from the fiscal point of view, on the occasion of the Kandir law and the pursuit of greater national competitiveness in global markets.

\section{KEYWORDS}

Regional economy; development; taxation; exports of primary products; Brazil.

\section{JEL CLASSIFICATION}

R11, H71, F14

\section{CONTENT}

Introduction 1. Economic dynamics and reprimarization of exports in Brazil; 2. Kandir Law: history and objectives; 3. The tax losses of Minas Gerais, Paraná, and Rio de Janeiro; 4. Conclusions; Bibliography. 


\section{INTRODUÇÃO}

Nas últimas décadas tem se observado um maior volume de questionamentos acerca do desenho federativo brasileiro, em especial sobre as relações da escala nacional com seus entes federados (estados e municípios). Os mecanismos de recolhimento/ partilha das receitas tributárias pelo território nacional vêm sendo apontados como parte importante das estratégias em direção à mais efetiva descentralização federativa, o que dota as unidades subnacionais de maiores condições para concepção/ implantação de políticas de desenvolvimento próprias.

O binômio coordenação-cooperação se apresenta sempre como um dos grandes desafios em regimes federativos, notadamente pela existência de conflitos entre os interesses dos diferentes níveis de governo/territórios. Crises de natureza federativa que envolvem o território brasileiro são relativamente recorrentes, algo creditado não somente às suas dimensões continentais, mas também à relativa juventude do atual pacto federativo, vigente desde a redemocratização, mais precisamente com a promulgação da nova Constituição Federal em 1988.

A industrialização por substituição de importações (1929-1979) logrou êxito em consolidar uma ampla e articulada estrutura econômica urbano-industrial, com a internalização de praticamente todos os principais ramos da indústria mundial naquele momento. Entretanto, as desigualdades regionais da produção foram em certa medida acentuadas com a preponderância do Sudeste, notadamente de São Paulo, como epicentro do dinamismo industrial. Ainda hoje, a maior marca do desenvolvimento capitalista brasileiro, do ponto de vista territorial, é a acentuada desigualdade regional, observada em diversas escalas e planos: não somente entre as unidades da federação, mas também entre municípios de um mesmo estado e, pior, dentro de um mesmo município.

Por isso, exatos trinta anos após a promulgação da Constituição Federal, os entes federativos da escala subnacional reclamam insuficiência de recursos e instrumentos próprios em prol de políticas ativas de desenvolvimento. A questão fiscal sempre salta ao debate, mormente pela situação financeira delicada e, por vezes, de total dependência de recursos da união, que estados e municípios apresentam. Nesse contexto, o presente artigo traz elementos para a compreensão de um dos mais criticados pontos sobre a realidade federativa brasileira: as grandes perdas fiscais que alguns estados têm tido resultantes da Lei Federal 87/1996, conhecida como

\section{Lei Kandir.}

A Lei Kandir foi criada com vista a aumentar a competitividade das exportações brasileiras no mercado internacional por isentar de tributação estadual a produção destinada ao mercado internacional. Isso, em prática, resulta na renúncia fiscal, 
por parte dos estados, de grande montante monetário, o que tem ensejado críticas sobre o grande peso que a estratégia nacional tem trazido a determinadas unidades da federação. Para além dos impactos produtivos derivados dos investimentos necessários à produção e suporte (logística, principalmente), a produção de commodities tem levado a questionamentos alusivos às perdas das regiões produtoras por ocasião de cumprimento de objetivos nacionais, em especial no tocante ao chamado federalismo fiscal.

Assim, esse artigo objetiva apresentar os efeitos fiscais da Lei Kandir para três unidades da federação: Minas Gerais, Rio de Janeiro e Paraná. A escolha do trio se baseou na importância que tem para as exportações brasileiras de produtos básicos, minério de ferro, petróleo e soja. O texto busca apresentar o contexto de formulação e promulgação da Lei Kandir e assinalar seu objetivo de robustecimento macroeconômico nacional.

Baseado em revisão da literatura e análise de dados secundários disponíveis nos principais órgãos de informação estatística do país, o artigo aponta que embora a lei também incorpore entre seus produtos não-tributáveis bens de maior sofisticação industrial, acabou por estimular a reprimarização nacional à medida que o barateamento relativo dos bens básicos (em termos de custos internos de produção) se fortaleceu com o superciclo das commodities, período de forte ascensão dos preços internacionais. Em conclusão, mostra-se que a via de inserção nacional aos mercados internacionais via maior especialização na produção/exportação de produtos primários tem tido efeitos sobre os territórios estaduais não somente com a baixa densidade e sofisticação produtiva, mas também sobre os cofres públicos, dado que as compensações financeiras vindas da União não têm alcançado, nem de perto, os montantes efetivamente renunciados.

Para tanto, o artigo se divide em três partes principais, além dessa introdução e uma conclusão. No tópico seguinte, apresenta-se um breve balanço sobre o debate em torno do papel da produção primária como eixo indutor do crescimento e da competitividade nacional. Em seguida, apresenta-se a chamada Lei Kandir, buscando situá-la temporalmente como elemento de política de inserção externa aos fluxos econômicos internacionais. Em seguida, apresentamos dados acerca das performances econômicas dos três estados da federação e concentramos esforços no entendimento sobre as renunciais fiscais e sobre os montantes compensatórios recebidos.

\section{DINÂMICA ECONÔMICA E REPRIMARIZAÇÃO DAS EXPORTAÇÕES NO BRASIL}

Assim como observado para a América Latina, a história econômica brasileira tem sido marcada pelo papel dos recursos naturais nos ciclos de crescimento/ 
desenvolvimento. Durante a etapa agroexportadora (até 1929), a especialização na produção de bens primários para atendimento do mercado externo dava a tônica do dinamismo nacional, logo substituída como centro dinâmico pelo crescimento urbano-industrial ensejado pela industrialização por substituição de importações (Ocampo, 2012). Segundo Serra (1982), mesmo durante o movimento industrializador, a produção de produtos primários detinha caráter estratégico, ou como base de cadeias industriais ou como fonte de divisas externas necessárias à composição do financiamento do modelo.

Ainda que o crescimento nacional tenha mudado seu eixo determinante de fora para dentro, as exportações ainda tinham um papel preponderante, contudo apresentando-se mais diversificadas, com a incorporação de bens manufaturados. Nesse sentido, Nonnenberg (2018, p. 11) assinala que as exportações brasileiras tiveram papel fundamental na determinação da atividade econômica nacional, tanto na fase de maior avanço da industrialização quanto nos períodos subsequentes, da década perdida aos Governos Lula (2003-2010). O autor destaca que durante 50 anos ininterruptos as exportações brasileiras, de modo agregado, cresceram ininterruptamente, mas apresentaram queda a partir de 2012, com exceção dos ramos ligados às exportações de animais e vegetais. Foi justamente o petróleo o produto exportado com a maior queda no pós-2011, fruto da combinação do turbulento cenário doméstico que envolve o setor com a queda nos preços internacionais da commodity.

Importante destacar que até fins dos anos 1990, a pauta exportadora brasileira era consideravelmente composta de produtos manufaturados ou bens mais elaborados (Nonnenberg, 2018). É a partir do segundo Governo FHC (1998-2002) que se nota uma inflexão em direção a maior presença de bens primários no conjunto transacionado pelo país, efeito direto da reorientação nacional em prol da busca por mais amplos e continuados saldos na balança comercial, exigidos pelo contexto macroeconômico. Assim, para Carneiro (2012), observou-se uma acelerada expansão da fronteira agrícola e mineral nacional, o que passou a suscitar preocupações acerca da mudança estrutural em curso no país e seus efeitos de médio e longo prazo sobre os territórios diretamente envoltos às cadeias produtivas baseadas em recursos naturais.

Do ponto de vista territorial, segundo Gorenstein e Ortiz (2018), notou-se a emergência de dinâmicas regionais cada vez mais dependentes da produção destinada à exportação. Nesse tempo, nas palavras de Silva (2013), a produção primária, de origem mineral ou agrícola, tornou-se booster do dinamismo econômico, e urbano, de várias partes do território nacional. Entre os principais produtos desse processo, 
destacam-se a soja, o minério de ferro e o petróleo, todos commodities com grande demanda no mercado internacional e caráter estratégico dentro da matriz produtiva internacional contemporânea.

Se do ponto de vista da escala nacional não é permitido falar em estrutura produtiva especializada, dado que o Brasil é uma economia em grande medida industrializada e setorialmente articulada, pode-se afirmar que para algumas de suas unidades subnacionais, estados e municípios, o perfil produtivo passou a se mostrar mais especializado e dependente da produção primária!'.

Ainda que os estados em análise neste artigo tenham importantes setores da indústria manufatureira nacional, tais como automóveis, química, refino, entre outros, o peso da produção de soja (Paraná), minério de ferro (Minas Gerais) e petróleo (Rio de Janeiro) tem crescido em grande velocidade, e isso torna essas atividades os pilares do dinamismo do produto interno bruto regional. Essas commodities foram determinantes para os ganhos de participação desses estados na economia brasileira, como apontado por Monteiro e Silva (2018) ${ }^{2}$.

Tanto o aumento das exportações quanto da participação dos produtos primários na economia brasileira resultam desse vasto contexto de mudanças observadas desde meados dos anos 1990. Desde então, o país adotou políticas setoriais pontuais em direção ao aumento das exportações, porém, de modo amplo, a mais importante ação a nosso ver, nesse sentido, foi a promulgação da Lei Kandir, cuja origem e objetivos são apresentados no tópico seguinte.

\section{LEI KANDIR: HISTÓRICO E OBJETIVOS}

A presente constituição brasileira data de 1988. Concebida em meio ao processo de redemocratização, após o fim do regime iniciado com o golpe militar de 1964, um de seus preceitos embutidos era o fortalecimento das relações federativas, com o encorajamento da descentralização político-administrativa em favorecimento às esferas subnacionais (estados e municípios).

Assim, no inciso II do artigo 155, a Constituição Federal indicava a competência das unidades da federação (os 26 estados mais o Distrito Federal) para o recolhimento de tributos sobre a circulação de mercadorias e sobre prestação de serviços de transporte interestadual e intermunicipal e de comunicação.

Para análise mais profunda ver Brandão (2016).

2 Entre 1995 e 2014, a participação dos três estados na economia brasileira, medida pelo valor adicionado bruto, foi de: Minas Gerais (8,6 \% para 9,1 \%), Paraná (5,8 \% para 6,1 \%) e Rio de Janeiro (11,2 \% para $11,7 \%)$. 
Essa importante fonte de receitas era entendida como passo central na consolidação da autonomia dos entes federados diante da esfera federal de poder, ponto considerado necessário ao desenvolvimento do país nessa nova etapa da vida democrática nacional. O novo imposto, vale ressaltar, viria em substituição ao antigo imposto sobre circulação de mercadoria (ICM), cuja responsabilidade quanto à disposição dos valores das alíquotas era do Congresso Nacional, mas que eram recolhidos pelos estados. Por fim, a Constituição determinava que o novo tributo — sua incidência e detalhes outros - deveria ser regulamentado por lei complementar específica da matéria, discutida e aprovada pelas casas que compõem o Congresso Nacional.

Pouco mais de meia década depois, o então deputado Antônio Kandir ${ }^{3}$ apresentou ao Congresso Nacional o Projeto de Lei Complementar 95 de 1996 que tratava das operações relativas ao Imposto sobre Circulação de Mercadorias e Serviços (ICMS). O Projeto de Lei buscava preencher lacunas existentes no texto original da constituição, e atendia determinação prevista no art. 146, III a, acerca do estabelecimento de normas gerais sobre a definição de tributos relacionados na Constituição e seus fatos geradores, bases de cálculo e contribuintes. Ademais, o projeto de lei também se justificava pelo atendimento ao art. $155, \S 2^{\circ}$, XII, que trata dos impostos de competência estadual e suas atribuições.

Após período de debate parlamentar, o projeto de lei foi aprovado pelo Congresso Nacional ainda no primeiro mandato do presidente Fernando Henrique Cardoso (1994-1998) e se tornou Lei Complementar 87, de 13 de setembro de 1996. Entre as diversas determinações da nova lei, a de maior alcance foi a não-incidência do novo imposto (Imposto sobre a Circulação de Mercadorias e Serviços — ICMS) sobre operações de exportação, que incluiu no texto também os produtos primários e semielaborados (artigos $3^{\circ}$, II e $32^{\circ}$, I).

Vale ressaltar que a inclusão desses produtos viria a ser uma mudança radical na proposição inicial da Constituição, dado que o texto de 1988 previa a não-incidência do futuro imposto apenas sobre produtos industrializados. De fato, o texto constitucional excluía explicitamente os produtos semielaborados ${ }^{4}$ e primários, e

Antônio Kandir foi deputado pelo Partido da Social Democracia Brasileira (PSDB) e doutorou-se em Economia pela Universidade Estadual de Campinas (Unicamp). Iniciou sua carreira na política em 1990, como secretário especial de Política Econômica do Ministério da Economia, Fazenda e Planejamento do Governo Collor (199093).

4 Segundo a Lei Complementar (LC) 65, de abril de 1991, produtos semielaborados são aqueles destinados ao exterior: I - que resultem de matéria-prima de origem animal, vegetal ou mineral sujeita ao imposto quando exportada in natura; II - cuja matéria-prima de origem animal, vegetal ou mineral não tenha sofrido qualquer processo que implique modificação da natureza química originária; III - cujo custo da matéria-prima de origem animal, vegetal ou mineral represente mais de sessenta por cento do custo do correspondente produto, apurado segundo o nível tecnológico do País. (Congresso Nacional, LC 65, art. 1). 
deixava, contudo, brechas para futuro tratamento acerca da inclusão destes no escopo do imposto. Adicionalmente, a nova lei revogava os termos da Lei 65/1991 e estabelecia enfim a não-incidência de tributos sobre produtos semielaborados, quando estes fossem exportados, e também a redução da carga tributária para estabelecimentos agrícolas e pastoris.

Na prática, a Lei Kandir, como ficou nacionalmente conhecida, vinha regulamentar o novo tributo e conferiu liberdade às unidades da federação na determinação dos percentuais a serem cobrados em seu respectivo território, desde que sob obediência às regras federais e através de decreto do governador do estado.

Logo no princípio ficou clara a orientação da Lei 87/1996 em prol do estímulo às exportações. Assim, ela estava coadunada às orientações da política econômica à época, de maior e mais rápida inserção nos mercados internacionais via especialização ricardiana clássica. Fato é que em meados dos anos 1990, após uma década e meia de pífio crescimento, baixos níveis de investimento e fragilidade financeira, as opções de exportação do país estavam bem reduzidas, pouco tendo sua grande, mas ainda incompleta, matriz industrial a oferecer competitivamente nos mercados internacionais, que já operavam em consonância com novos arranjos produtivos inter (e intra) empresa e com base tecnológica em rápida transformação. Nesse cenário, não somente a estabilização monetária, mas principalmente o crescimento, segundo os formuladores de política econômica do Governo FHC, dependiam do desempenho das exportações.

As interpretações sobre o significado e transformações derivadas da Lei Kandir tendem a destacar seu papel normativo e como instrumento dentro da política econômica nacional de curto prazo, pouco se atendo aos efeitos de médio e longo prazo.

Varsano (1998), por exemplo, destaca o papel normativo da lei no sentido de preenchimento das lacunas deixadas pela Constituição Federal e a introdução de importantes alterações na principal fonte de arrecadação das unidades subnacionais. Dall'acqua (2001), por seu turno, destaca o papel da lei na redução do chamado Custo Brasil e no conseguinte incremento da competitividade nacional. Soares (2007) e Riani e Albuquerque (2008) apontam que no período anterior a 1996, as exportações de diversos produtos semielaborados e de todos os primários eram tributadas de maneira demasiada e isso levava à redução de competitividade no mercado internacional.

Destaca-se que nos primeiros anos do Plano Real, o debate sobre os déficits externos era recorrente, principalmente porque a estratégia de estabilização 
monetária pressupunha instrumentos que dependiam do maior saldo comercial para seu sucesso. A necessidade de divisas externas para se manter a política do real forte passava pelo contínuo e crescente saldo da balança comercial. Por isso, o estímulo às exportações era central para a política macroeconômica nacional, notadamente porque o uso da âncora cambial como estratégia de realinhamento dos preços relativos internos pressionava o saldo comercial externo por conta da expansão das importações.

Riani e Albuquerque (2008) também afirmam que a desoneração de parte do ICMS poderia levar ao aumento da taxa de investimento dentro do território nacional, dado que as unidades da federação poderiam estimular o desenvolvimento com redução das alíquotas e fomentar o investimento em especial nos setores de bens de capital. Nesse sentido, Dall'acqua (2001, p. 6) aponta que: "ao desonerar as compras de bens de capital, ela (a lei) criou um estímulo para o investimento interno, ou seja, para alavancagem do desenvolvimento econômico brasileiro (...) uma contribuição positiva para se equacionar dois importantes problemas macroeconômicos brasileiros quais sejam o desequilíbrio das contas externas e o apático crescimento econômico registrado após o Plano Real."

Não obstante estimular as exportações e apontar possibilidades de ampliação do investimento interno, a Lei Kandir trazia efetivas renúncias fiscais às unidades da federação. Ao reduzir a base tributável dos estados e do Distrito Federal, dado que não apenas os produtos finais eram isentos de impostos, era garantido aos exportadores o aproveitamento integral de crédito de imposto relativo aos insumos utilizados nas mercadorias exportadas (art. 21 da LC 87/1996), ou seja, a lei impunha um montante de perdas aos territórios exportadores, sendo mais grave a situação daqueles cujas pautas produtivas estivessem fortemente atreladas à produção para exportação.

Os efeitos da desoneração atingiram, primeiramente, de modo mais duro os territórios produtores de bens primários e semielaborados. Como os produtos industriais já eram isentos de tributação desde fins dos anos 19805, as regiões que ainda exportavam esses produtos para o exterior não sentiram o efeito da nova lei. Contudo, as regiões cuja base produtiva para exportação era em grande medida baseada em recursos naturais, sentiram quase que imediatamente que a nova lei traria consideráveis perdas fiscais.

Por antever possíveis perdas fiscais por parte dos territórios exportadores, o art.

\footnotetext{
5 Apenas para detalhar, como destaca Rezende (2009), desde a edição do Decreto de Lei n406/1968 havia a determinação de não incidência do antigo ICM na exportação de produtos industrializados. Além disso, aumentou-se simultaneamente a alíquota interna do ICM aplicada no Sul e no Sudeste (regiões mais industrializadas) para $17 \%$, com o objetivo de compensar o efeito dessa desoneração.
} 
31 da Lei Kandir trazia um mecanismo de compensação. Conhecido como Seguro Receita, previa repasses do Governo Federal aos estados produtores nos casos em que a receita apurada fosse inferior à observada no período-base. Originalmente, o texto da lei propunha que essa compensação seria feita até o exercício financeiro de 2002, e assinalava a possibilidade de prorrogação até 2006. Uma complexa fórmula determinava o quanto seria repassado para cada estado, o que envolvia o montante arrecadado de ICMS em relações aos demais entes federativos e às receitas da União coletadas em seu território. O Seguro Receita, que a princípio seria temporário, foi constantemente prorrogado e por meio da Lei Complementar 102, de julho de 2000, foi transformado em um Fundo Orçamentário de Compensação aos estados.

Contudo, a Lei Complementar 115, de 2002, alterou tanto a Lei Complementar 102/2000, assim como o art. 31 da Lei 87/1996, e estipulou que a entrega do valor total do Seguro Receita seria definido a cada ano a partir de 2006 via Lei Orçamentária Anual (LOA) e fixou os percentuais previamente determinados e devidos pela União aos estados produtores (e seus municípios), conforme exposto na Tabela 1.

Tabela 1. Percentual de Repasse Federal às Unidades da Federação

\begin{tabular}{llll}
\hline \multicolumn{1}{c}{ UF } & \multicolumn{1}{c}{$\%$} & \multicolumn{1}{c}{ UF } \\
\hline Acre & 0,09104 & Paraíba & 0,28750 \\
\hline Alagoas & 0,84022 & Paraná & 10,08256 \\
\hline Amapá & 0,40648 & Pernambuco & 1,48565 \\
\hline Amazonas & 1,00788 & Piauí & 0,30165 \\
\hline Bahia & 3,71666 & Rio de Janeiro & 5,86503 \\
\hline Ceará & 1,62881 & Rio Grande do & 0,36214 \\
\hline $\begin{array}{l}\text { Distrito Fede- } \\
\text { ral }\end{array}$ & 0,80975 & Norte & \\
\hline Espírito Santo Grande do & 4,26332 & Rondônia & 0,24939 \\
\hline Goiás & 1,33472 & Roraima & 0,03824 \\
\hline Maranhão & 1,67880 & Santa Catarina & 3,59131 \\
\hline Mato Grosso & 1,94087 & São Paulo & 31,14180 \\
\hline $\begin{array}{l}\text { Mato Grosso } \\
\text { do Sul }\end{array}$ & 1,23465 & Sergipe & 0,25049 \\
\hline Minas Gerais & 12,9041 & Tocantins & 0,07873 \\
\hline Pará & 4,36371 & Total & 100 \\
\hline Fon & & & \\
\hline
\end{tabular}

Fonte: Lei 115, de dezembro de 2002 
Dado os percentuais previstos, fica claro que o instrumento de compensação aos entes federados não conseguiria cobrir suas perdas por ocasião da desoneração tributária. Em um cenário otimista, talvez cobrisse tão-somente parte dos valores baseados na estimativa prévia de perdas de receita, mas não nas efetivas perdas. Isso porque a alíquota média cobrada de ICMS pelos estados brasileiros gira em torno de $18 \%$. Com base nisso, Riani e Albuquerque (2008) afirmam que o Seguro Receita não foi introduzido na lei para ressarcir os estados pelas perdas da arrecadação do ICMS, mas apenas para assegurar a manutenção de um certo nível de receitas desse imposto.

Outro mecanismo compensatório criado para os estados foi o Auxílio Financeiro para Fomento das Exportações, instituído pela Medida Provisória 193, de 24 de junho de 2004. Esse fundo disponibilizava recursos da ordem de R\$900 milhões (aproximados US\$241,36 milhões pelo câmbio à época), que seriam distribuídos na razão de um doze avos a cada mês, mediante o envio das informações pelos estados sobre o aproveitamento do montante de ICMS cobrado nas operações anteriores a desoneração.

A Medida Provisória foi transformada na Lei 10.966, de novembro de 2004, e nos anos subsequentes os recursos do fundo foram incluídos na Lei Orçamentária Anual (LOA) e liberados em época apropriada por intermédio de Medida Provisória ou Lei Ordinária (Secretaria do Tesouro Nacional, 2014, p. 1-2). Riani e Albuquerque (2008) apontam que esse auxílio foi fruto de negociações que envolveram mudanças tributárias da Emenda Constitucional 42/2003 e passou a ser relevante para os estados quando, junto aos fundos orçamentários, substituiu no longo prazo os ressarcimentos que já vinham se reduzindo em seu contexto original.

Mesmo com os instrumentos compensatórios criados, muitos entes subnacionais ainda consideram os valores repassados insuficientes e muito aquém dos valores que aufeririam caso não existisse a Lei Kandir. Vale destacar que, antes da promulgação da lei, alguns estados tinham uma parte significante de suas receitas originadas da tributação de produtos primários e semielaborados para exportação.

Ainda sobre esse ponto, vale destacar que para Soares (2007), não obstante almejar incentivar o investimento interno, inclusive na produção de produtos industriais mais elaborados (pensados para a exportação), o que se percebia era o oposto. $\mathrm{O}$ autor sustenta que haveria estímulo às exportações de produtos com baixo valor agregado, o que de certa forma poderia ajudar a deteriorar a indústria nacional.

O citado autor argumenta e dá como exemplo o complexo da soja, em suas palavras: "antes da aprovação da 'Lei Kandir', a soja em grão sofria a incidência do ICMS 
na exportação; já o óleo de soja escapava da tributação, uma vez que era considerado produto industrializado. Dessa forma, havia um incentivo ao esmagamento de soja no País. Depois da aprovação da Lei, dizem os críticos, o volume de esmagamento de soja no País diminuiu, e o grão brasileiro estaria sendo esmagado em países vizinhos" (Soares, 2007, p. 13).

Essa tendência se reforçou com o cenário econômico internacional pós-sanção da lei. O crescimento econômico da China levou ao aumento da demanda mundial de matérias-primas o que fez dessa nação o principal parceiro comercial do Brasil. A elevação da exportação brasileira de commodities levou a superávits na balança comercial e, em contrapartida, a maiores perdas causadas pela Lei Kandir.

Na última década, tanto no auge do ímpeto exportador de commodities quanto no momento de crise econômica, os custos que a Lei Kandir tem trazido aos estados produtores têm se tornado objeto de preocupação e debate, em especial quanto a seu papel no reforço ao fenômeno da Guerra Fiscal.

Como já apontado, a Constituição de 1988 permitiu a cada estado determinar de maneira autônoma a sua alíquota de ICMS, o que só veio a ser alterado com a Emenda Constitucional 42/2003, que passou a limitar o ajuste adicional da alíquota em até dois pontos percentuais. Ainda assim, isso fez com que os estados tivessem mais liberdade e mantivessem um grau considerável para competição entre os entes subnacionais na busca por novos investimentos.

A busca pela estabilização macroeconômica nos anos 1990 envolveu os governos estaduais e isso os obrigou a ter maior controle do ponto de vista fiscal e os levou à busca por novas fontes de receita. Vieira (2013, p. 156) ressalta que "(...) nos anos iniciais do Plano Real (1994-1997), a Guerra Fiscal reapareceu e assumiu amplitude inusitada, envolvendo número crescente de estados, benefícios cada vez mais vantajosos e o engajamento de muitos municípios como coadjuvantes ativos nas empreitadas hostis montadas para a atração de empreendimentos produtivos".

Para Vieira (2013), a Guerra Fiscal foi um fenômeno que antecedeu a Lei Kandir, mas que iniciou, após sua promulgação, um novo ciclo mais acirrado de competição predatória entre os entes federados. Dado que o ICMS é "individualmente a maior fonte de receitas do país" (Giambiagi e Além, 2011, p. 257), tem-se uma contínua corrida por mais receitas, ainda que a taxas percentuais menores, via atração de novos investimentos. A título de ilustração, em 2016, o imposto representava cerca de 6,6 \% do PIB nacional, o que demostra seu peso para as finanças públicas em nível subnacional. E mais: a importância do ICMS para os entes subnacionais ultrapassa a escala do meio (estadual) dado que os municípios brasileiros têm garantido $25 \%$ do total arrecadado (CF, art. 158, IV). 
Em função das desigualdades regionais, observa-se uma grande concentração do recolhimento do ICMS na região mais desenvolvida do país, o Sudeste (Gráfico 1). Essas diferenças, de certa forma, também impactam a disputa entre as unidades federativas, pois tendem a estimular que estados menos favorecidos busquem a qualquer custo uma forma de aumentar sua arrecadação. Por outro lado, os estados que já concentram boa parte da arrecadação também desejam se manter na posição atual, e isso causou uma corrida para se manter no topo ou, no primeiro caso, alcançá-lo.

Apesar da Guerra Fiscal ter atingido fortemente o núcleo da economia brasileira, o estado de São Paulo ainda responde por mais de 32 \% do ICMS nacional (R\$ 132.259.226,00 em 2017, em valores nominais). O montante arrecadado por São Paulo é um pouco menor do que os totais somados das regiões Nordeste, Norte e Centro-Oeste.

Gráfico 1. Arrecadação de ICMS por região: 2017 (em R\$)

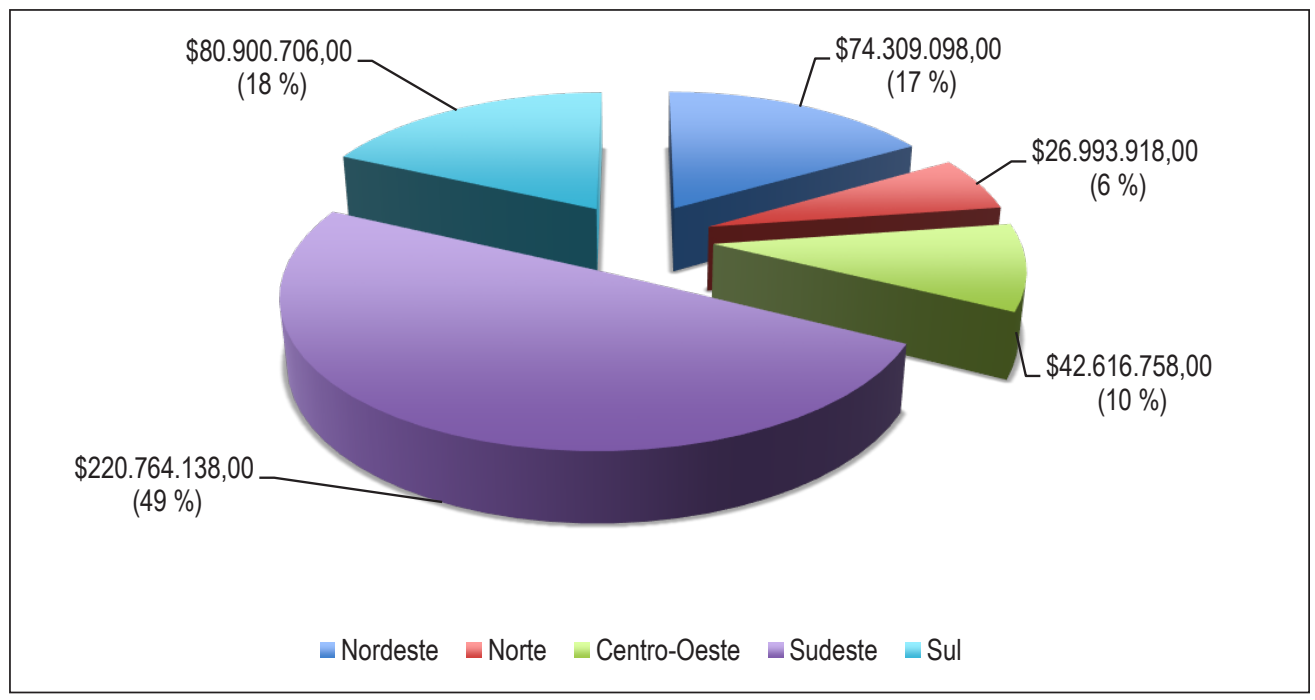

Fonte: elaboração própria a partir de dados do Ipeadata (2018)

Para Vieira (2013), isso gera um problema de coordenação ocasionado pela debilidade ou inexistência de mecanismos de coordenação intergovernamentais. Portanto, a falta de atuação do governo central faz com que as políticas solidárias percam a sua eficácia e assumam maior expressão as autocentradas, que perpetuam ainda mais os problemas de coordenação. Piancastelli e Perobelli (1996, p. 23) afirmam que quase todos os estados brasileiros têm concentrado esforços em 
políticas voltadas à atração de investimentos e à geração de empregos por esse tipo de política fiscal, o que caracteriza, assim, uma Guerra Fiscal.

Arvate e Biderman (2005) chamam esse cenário de competição predatória (race to the bottom) e o caracterizam como uma competição baseada na concessão de renúncia fiscal sobre o ICMS de empresas que escolham investir em dado território. Em sentido oposto ao esperado, essa competição não conduz ao aumento da receita tributária, nem a federal, tampouco a subnacional, o que prejudica o financiamento e a oferta de serviços públicos essenciais. Destacam ser esse "um problema típico da federação brasileira, em que os estados oferecem incentivos fiscais a grandes empresas para que elas se instalem em seu território". Segundo Arvate e Biderman (2005), o resultado é a concessão de incentivos cada vez maiores, o que exige que outros contribuintes, não beneficiários dos incentivos, sejam excessivamente tributados, para manter o financiamento do setor público.

Por fim, há o reconhecimento de que a ausência de um projeto nacional de desenvolvimento é um elemento catalisador do comportamento deletério da Guerra Fiscal. Como destacam Monteiro et al. (2017, p. 34), é notório "o reconhecimento da guerra fiscal ser um problema federativo importante e que deve ter uma solução de encaminhamento". Porém, apontam que em um contexto de ausência de políticas nacionais de desenvolvimento potencializadoras de crescimento nas regiões, a atração de empreendimentos por meio de isenções e subsídios fiscais, financeiros e creditícios é um dos poucos meios disponíveis para regiões de baixo nível de desenvolvimento e com frágil tecido de infraestrutura urbana e social.

\section{AS PERDAS FISCAIS DE MINAS GERAIS, PARANÁ E RIO DE JANEIRO}

Entre os grandes centros exportadores do país, Minas Gerais, Rio de Janeiro e Paraná se destacam, pois ocupam a $2^{a}$, $3^{a}$ e $4^{a}$ posição, respectivamente, logo atrás de São Paulo. Esses três estados foram escolhidos como objetivo de análise, também porque têm a estrutura produtiva fortemente assentada sobre a produção de commodities.

Minas Gerais (MG) e Rio de Janeiro (RJ) se destacam como principais centros produtores de recursos naturais não-renováveis (minério de ferro e petróleo), ao passo que o Paraná (PR) se destaca pelo complexo da soja. Juntos representam pouco mais da terça parte das exportações brasileiras. MG responde por 11,6 \% do total nacional, RJ e PR respondem por 10,1 \% e 8,3\%, respectivamente (MDIC, 2018). Também estão entre os que mais reclamam perdas financeiras por ocasião da renúncia fiscal, uma vez que os dois primeiros têm vivido aguda crise nos últimos anos, para as quais muito contribuiu a ruptura do ciclo de alta dos preços das commodities no mercado internacional. 


\section{Minas Gerais}

Minas Gerais é um dos maiores estados brasileiros em termos de dimensões territoriais - $586.732 \mathrm{~km}^{2}$. Com 853 municípios e população de aproximadamente 21 milhões de habitantes, tem sua economia baseada em produção agrícola, alguns ramos manufatureiros e serviços. Porém, destaca-se no cenário nacional como grande exportador de minerais, notadamente o minério de ferro, e responde por 45,2 \% das exportações brasileiras do produto.

O Gráfico 2 mostra a trajetória das exportações do estado por tipo de produto. Nota-se a forte ascensão dos valores referentes aos produtos básicos no começo dos anos 2000. Esse movimento se manteve até meados da presente década, quando houve rompimento do boom das commodities.

\section{Gráfico 2. Exportações MG (FOB) US\$ (1996-2017)}

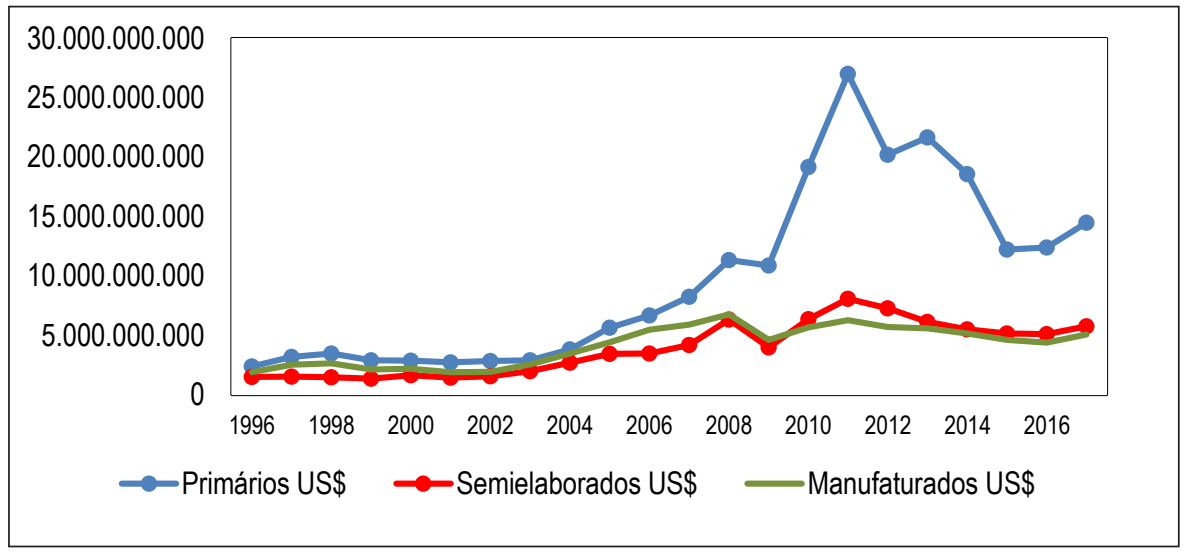

Fonte: elaboração própria a partir de dados do MDIC (2018)

Não apenas o minério de ferro forma a pauta exportadora do estado. Cerca de $70 \%$ do total exportado tem por base produtos primários ou semielaborados, com destaque para outros minerais, café, soja e carne (Tabela 2). O movimento internacional explica diretamente a trajetória e performance estadual, basta indicar os principais destinos das suas exportações. Em 1999, por exemplo, os grandes parceiros comerciais do estado, do ponto de vista de suas exportações, eram, em ordem, os Estados Unidos da América (EUA), a Itália e o Japão. Em 2017, por sua vez, a China, os EUA e a Argentina ocuparam as três primeiras posições. É importante registrar que nesse ano, a China respondia por 28,81 \% das exportações estaduais, percentual bem acima do alcançado pelos EUA em 1999, de 18,01 \%, o que indica uma clara concentração da pauta exportadora de Minas Gerais, não apenas do ponto de vista do produto, mas também da destinação geográfica. 
Robson Dias Da Silva y Gabriela Mello Gonçalves

Tabela 2. Principais produtos exportados por Minas Gerais (2017)

\begin{tabular}{lrc}
\hline \multicolumn{1}{c}{ Produtos } & US\$ FOB & Part. \% \\
\hline Total geral & 25.349 .874 .338 & 100 \\
\hline Minérios de ferro não aglomerados & 8.281 .182 .686 & 32,67 \\
\hline Café não torrado, não descafeinado, em grão & 3.437 .872 .841 & 13,56 \\
\hline Ferronióbio & 1.341 .552 .334 & 5,29 \\
\hline Outros açúcares de cana & 1.198 .280 .069 & 4,73 \\
\hline Soja, mesmo triturada, exceto para semeadura & 990.450 .657 & 3,91 \\
\hline Ouro em barras, fios e perfis de seção maciça & 819.577 .007 & 3,23 \\
\hline Pasta quim. madeira de n/conif. a soda/sulfato & 630.242 .324 & 2,49 \\
\hline Carnes desossadas de bovino, congeladas & 497.657 .835 & 1,96 \\
\hline Ferro fundido bruto não ligado & 470.862 .119 & 1,86 \\
\hline Minérios de ferro aglomerado p/ de pelotizacão & 398.791 .969 & 1,57 \\
\hline Total dos principais produtos & 18.066 .469 .841 & 71,27 \\
\hline
\end{tabular}

Fonte: MDIC — Secex (2018)

\section{Rio de Janeiro}

O Rio de Janeiro é a segunda maior economia regional do país, e destaca-se economicamente por alguns ramos dos serviços e projetos pontuais da indústria manufatureira. Desde meados dos anos 1990, tem cabido ao petróleo o dinamismo econômico e produtivo estadual. Com aproximadamente 6,8 milhões de habitantes que ocupam um dos menores territórios $\left(43.781,59 \mathrm{~km}^{2}\right)$ no cenário brasileiro, o estado tem enfrentado profunda crise econômica e social. Desde 2014, as finanças públicas e os investimentos no território têm sido impactados pela queda do preço do petróleo no mercado global e pelas ações de combate à corrupção que atingiram em cheio a grande articuladora da indústria de petróleo do país, a Petrobrás.

O Gráfico 3 mostra que a trajetória fluminense se assemelha, em tendência, a de Minas Gerais. Muito embora possa se perceber maior volatilidade nas exportações de produtos primários (petróleo), em função das razões já explicitadas. Desde 2005 também se nota uma maior participação das exportações de produtos manufaturados, resultado dos investimentos em setores-chave, dentro do contexto de Guerra Fiscal, que escolheram o território do estado como plataforma de produção para mercados externos, especialmente o Cone-Sul.

Os dados mostram que até o começo dos anos 2000, as exportações do Rio de Janeiro não eram tão concentradas nos produtos primários, já que houve uma melhor distribuição entre esses e os demais grupos de produtos. Inclusive, até 2004, as exportações de produtos manufaturados superavam a soma das demais. Esse 
cenário só se alterou com o aumento da exportação de óleos brutos de petróleo (2005), o que aproximou a trajetória estadual dos casos de Minas Gerais e do Paraná.

Gráfico 3. Exportações RJ (FOB) US\$ (1996-2017)

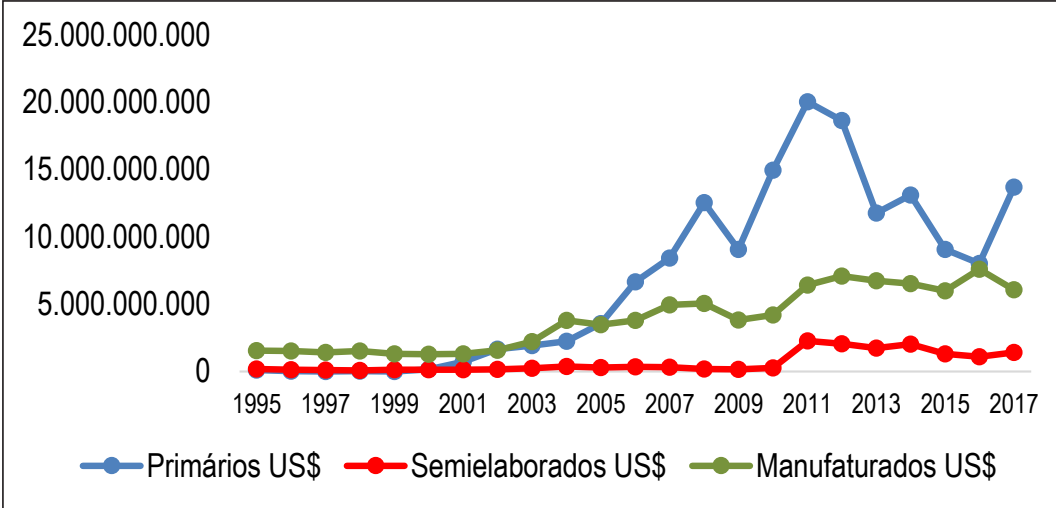

Fonte: elaboração própria a partir de dados do MDIC — Secex (2018)

Apesar da presença de importantes segmentos da indústria manufatureira em sua pauta exportadora, o petróleo passou a ter forte preponderância, por conta da conjugação de expansão da produção física e dos preços. Somente os óleos brutos de petróleo representaram mais de 60 \% do total exportado em 2017 (Tabela 3). Do ponto de vista da destinação geográfica, a China e os EUA ocuparam a liderança em 2017, que pertencia aos EUA e à Argentina em 1999 (MDIC, 2018).

Tabela 3. Principais produtos exportados pelo Rio de Janeiro (2017)

\begin{tabular}{lrc}
\hline \multicolumn{1}{c}{ Produtos } & US\$ FOB & Part. \% \\
\hline Total geral & 21.711 .783 .959 & 100 \\
\hline Óleos brutos de petróleo & 13.122 .475 .930 & 60,44 \\
\hline Barcos-faróis/guindastes/docas/diques & 903.820 .623 & 4,16 \\
\hline Automóveis com motor explosão & 815.762 .950 & 3,76 \\
\hline Outros tubos flexíveis de ferro ou aço & 721.872 .803 & 3,32 \\
\hline Outros prods. semimanuf. ferro/aço, c < 0,25\% & 710.152 .362 & 3,27 \\
\hline Produtos semimanufaturados, de outras ligas & 638.758 .654 & 2,94 \\
\hline Minérios de ferro não aglomerados & 513.077 .236 & 2,36 \\
\hline Fuel-oil & 410.215 .209 & 1,89 \\
\hline Consumo de bordo - combustíveis para aeronaves & 285.513 .771 & 1,32 \\
\hline Torneiras e outros dispositivos para canalizações & 230.302 .741 & 1,06 \\
\hline Total dos principais produtos & 18.351 .952 .279 & 84,52 \\
\hline
\end{tabular}

Fonte: MDIC — Secex (2018) 


\section{Paraná}

O Paraná é o único entre os estados objetos de análise desse estudo que não está localizado na macrorregião Sudeste do Brasil. Situa-se na região Sul, fazendo divisa com São Paulo e sendo um importante centro econômico nacional. Além da produção agropecuária, destaca-se como principal produtor de energia elétrica, tem importante papel logístico-portuário e é o mais importante hub do Brasil setentrional com os países do Cone-Sul. Com 199.307,94 km² de território, tem população da ordem de 11.320.892 milhões de pessoas, muitas das quais dependentes de empregos associados à produção primária.

Em comparação com Minas Gerais e Rio de Janeiro, é o estado que apresenta maior importância da exportação de produtos manufaturados em sua pauta de comércio exterior, tanto que entre 1999 e 2009, o volume exportado desse tipo de produto superava o de produtos básicos (Gráfico 4). De 2009 em diante, após forte queda seguida de certa recuperação, os produtos manufaturados passam a ter importância menor para composição das exportações paranaenses do que os produtos primários. Ao analisar a pauta exportadora do estado, verifica-se que não obstante a presença relevante de automóveis, os produtos primários e semielaborados representam mais de 50 \% das exportações (Tabela 4).

Gráfico 4. Exportações PR (FOB) US\$ (1996-2017)

10.000 .000 .000
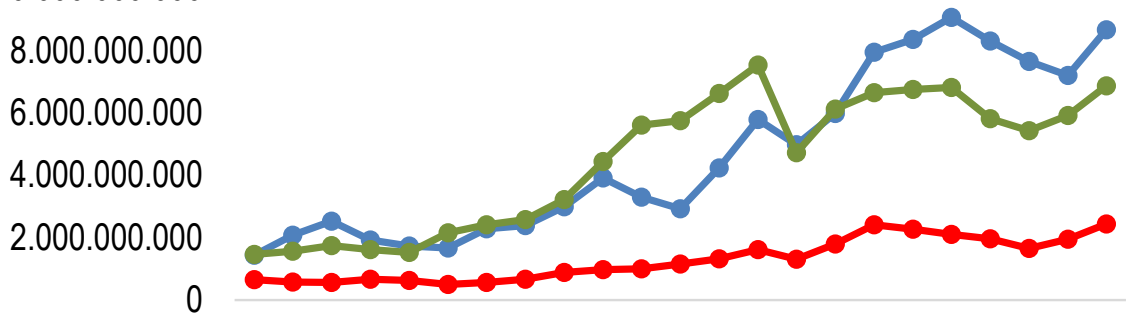

199519971999200120032005200720092011201320152017

$\multimap$ Primários US\$ $\rightarrow$ Semielaborados US\$ $\multimap$ Manufaturados US\$

Fonte: elaboração própria a partir de dados do MDIC — Secex (2018)

Do ponto de vista da destinação geográfica, fica patente as fortes conexões regionais com o mercado do Cone-Sul. Desde 1999, a Argentina e o Paraguai figuravam entre os 10 maiores parceiros comerciais do estado. Em 2017, a China se posicionava como principal parceira, seguida da Argentina, e não dos EUA, como observado nos casos de Minas Gerais e do Rio de Janeiro. 
Exportações e o desenvolvimento regional: um balanço da Lei Kandir para o Rio de Janeiro, Paraná e Minas Gerais

Tabela 4. Principais produtos exportados pelo Paraná (2017)

\begin{tabular}{lcc}
\hline \multicolumn{1}{c}{ Produtos } & US\$ FOB & Part. \% \\
\hline Total Geral & 18.082 .394 .413 & 100 \\
\hline Soja, mesmo triturada, exceto para semeadura & 4.136 .594 .956 & 22,88 \\
\hline Pedaços e miudezas, comest. de galos & 1.646 .141 .075 & 9,10 \\
\hline Outros açúcares de cana & 972.322 .308 & 5,38 \\
\hline Bagaços etc., da extr. do óleo de soja & 945.806 .773 & 5,23 \\
\hline Automóveis com motor explosão & 891.239 .545 & 4,93 \\
\hline Carnes de galos/galinhas n/cortadas & 675.481 .789 & 3,74 \\
\hline Milho em grão, exceto para semeadura & 469.743 .492 & 2,60 \\
\hline Pasta quim. madeira de n/conif. a soda/sulfato & 433.154 .036 & 2,40 \\
\hline Óleo de soja, em bruto, mesmo degomado & 394.338 .573 & 2,18 \\
\hline Madeiras compensadas espessura não superior a 6 mm & 383.267 .229 & 2,12 \\
\hline Total dos principais produtos & 10.948 .089 .776 & 60,56 \\
\hline
\end{tabular}

Fonte: MDIC — Secex (2018)

\section{Os três estados, as exportações e as perdas da Lei Kandir}

Seguindo a análise das trajetórias e pauta exportadoras de Minas Gerais, Rio de Janeiro e Paraná, cabe analisar as perdas e compensações recebidas por cada um desses estados no contexto de aplicação dos princípios da Lei Kandir. Os principais produtos da pauta exportadora de cada estado têm sido usados como alavancas para o crescimento econômico nacional e, em certa medida, do regional. No entanto, o incremento do volume produzido/exportado tem chamado atenção para as fragilidades e potenciais desperdiçados no tocante ao desenvolvimento regional. Há uma preocupação muito grande com processos de crescimento econômico export - oriented que, apesar de algum grau de benefícios trazido aos territórios produtores, mostram-se subutilizados em termos de potenciais de desenvolvimento das forças produtivas e melhorias sociais. Minas Gerais, Rio de Janeiro e Paraná são os espaços de maior preocupação dentro desse contexto, dado que produzem as três grandes commodities da economia brasileira.

O Gráfico 5 apresenta comparativamente a dinâmica de exportação dessas três commodities. Primeiramente, nota-se que a trajetória da soja foi menos cíclica, ainda que de menor montante financeiro, do que as relativas aos demais bens. Esse padrão é resultado de um ritmo menor da expansão dos preços do grão relativamente ao 
observado com o minério de ferro e, especialmente, o petróleo. No caso desse último, o ano de pico foi 2012, quando pouco mais de 28 bilhões de dólares foram exportados pelo Rio de Janeiro. Uma acentuada retração se observa e culmina com o piso de pouco menos de 8 bilhões de dólares em 2016. Uma leve recuperação foi notada no ano seguinte, como resultado da recuperação ainda que tímida dos preços internacionais.

Em relação às exportações de minério de ferro de Minas Gerais, pode-se dizer que a trajetória é bem similar à do Rio de Janeiro. Entre 2011 e 2012, ocorreu o pico de exportações (14 bilhões de dólares) e chegou a menos da metade desse montante em 2015, a partir de quando se nota uma leve recuperação.

Gráfico 5. Exportações de soja (PR), dos minerais de ferro (MG) e dos óleos brutos de petróleo (RJ) US\$ FOB (1999-2017)

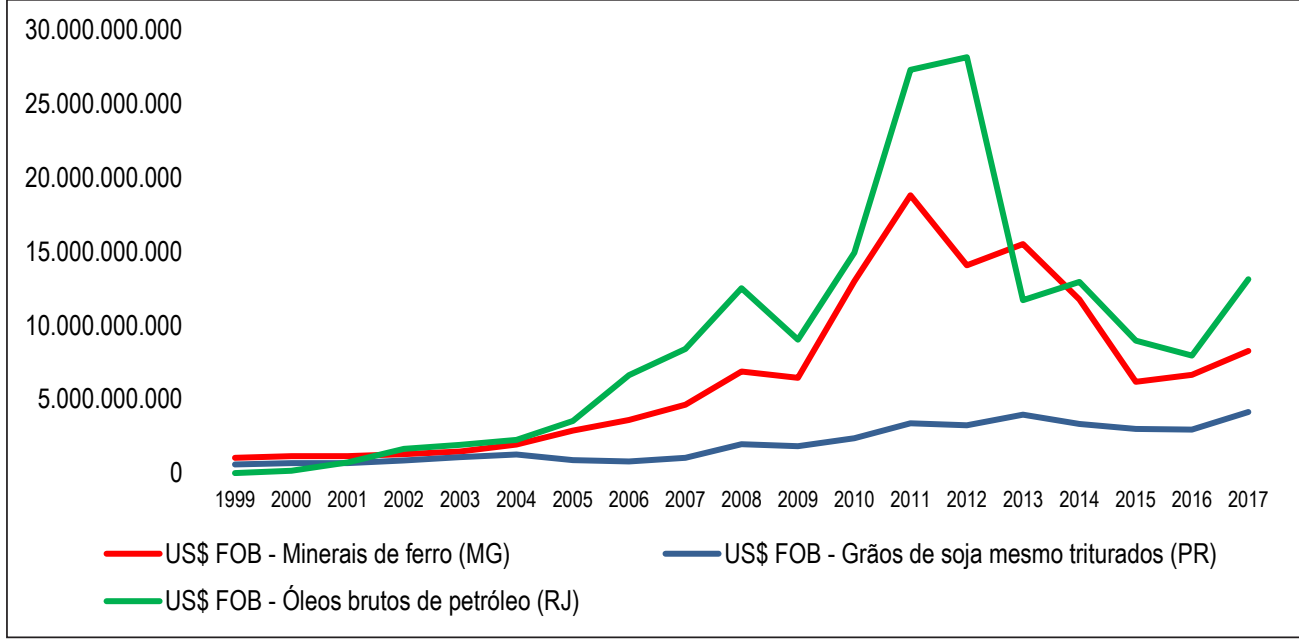

Fonte: elaboração própria a partir de dados do MDIC — Secex (2017)

Do ponto de vista da arrecadação do ICMS, chama atenção que o volume arrecadado por Minas Gerais superou o do Rio de Janeiro logo no começo do presente século, o que aponta que o estado mineiro tem uma base tributária mais ampla (Gráfico 6). Do trio, quem sofreu o maior impacto e parece encontrar mais dificuldade de recuperação é justamente o Rio de Janeiro, estado que, em 2015, decretou estado de calamidade financeira por conta da grave crise fiscal-econômica enfrentada e, mais recentemente, foi alvo da primeira ação de intervenção federal por motivos de segurança pública em um ente subnacional desde a redemocratização. De todo modo, observa-se que a variação real das exportações foi bem superior à variação do ICMS arrecadado para cada estado. 
Gráfico 6. Índice Variação Real do ICMS arrecado por Minas Gerais, Paraná e Rio de Janeiro $(1996=100)$

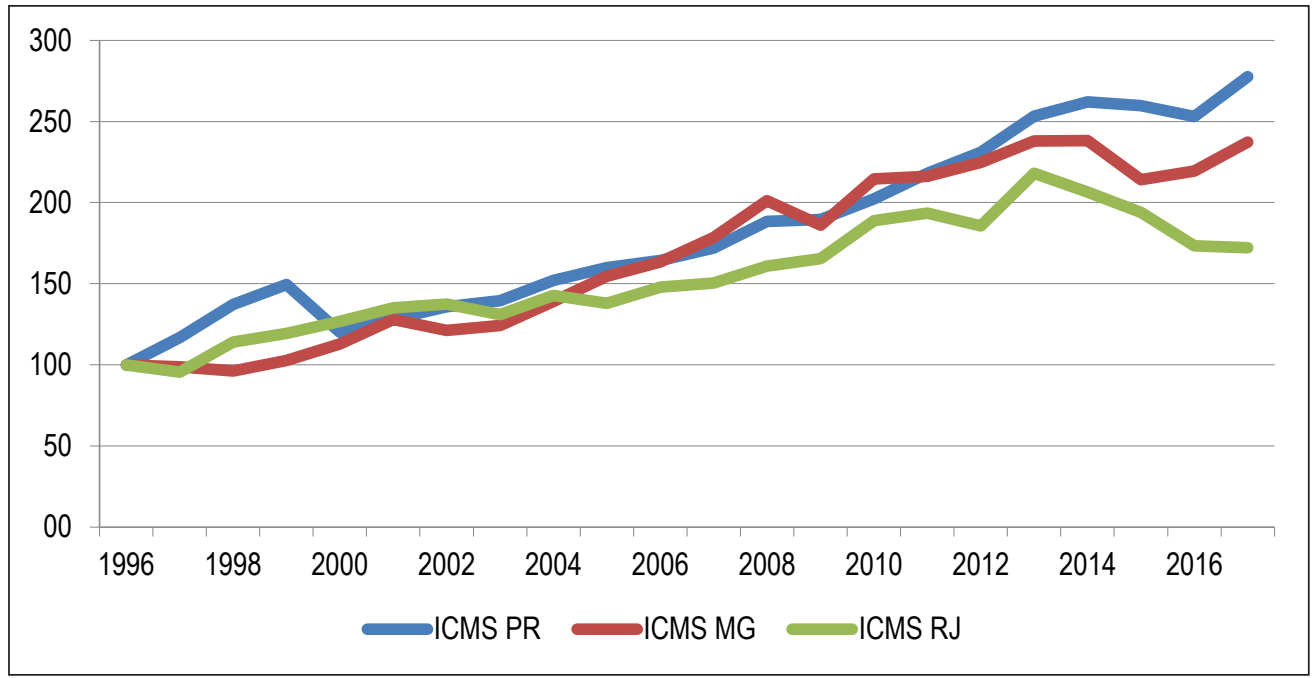

Fonte: elaboração própria a partir de dados do Ipeadata (2018)

Dados da Fundação Amazônica de Amparo a Estudos e Pesquisas (Fapespa, 2017) apontam que entre todas as unidades da federação brasileira, Minas Gerais é aquela que acumula o maior quantitativo de perdas por conta das desonerações impostas pela Lei Kandir. Vale destacar, como indicado no Gráfico 7, que desde o primeiro ano de vigência da lei, o estado passou a ter consideráveis perdas fiscais. Apesar das transferências terem aumentado entre 1998 e 1999, elas efetivamente nunca chegaram a superar os valores desonerados.

Nota-se inclusive um padrão cíclico das perdas. Nos anos de maior exportação de minério de ferro, como 2011 e 2013, que seriam os anos de maior arrecadação, acabaram sendo os anos de maior perda, não contrabalanceadas pelas compensações, principalmente em 2013. Ou seja, o estado de Minas não usufruiu em arrecadação do ciclo de exploração de seus recursos minerais e a perda é diretamente proporcional ao aumento da exportação. Em função de ter um volume de exportação mais modesto, o Paraná não sentiu inicialmente os impactos da lei de forma tão abrupta. Verifica-se que suas perdas começam apenas a partir de 2001 (Fapespa, 2017). Nesse período, os produtos de exportação paranaenses passaram a ter maior relevância no cenário internacional e, por conseguinte, o estado passou a ter perdas superiores. Destaca-se que nos primeiros anos de transferências o estado recebeu compensações acima do recebido por Minas Gerais, embora suas perdas tenham sido inferiores. A perda do Paraná, assim como de Minas Gerais, é 
diretamente proporcional ao aumento das exportações de seu principal produto, no caso, a soja, como se verifica em 2017.

Gráfico 7 - Perdas brutas de arrecadação de ICMS desonerado pela Lei Kandir e valor das compensações financeiras de 1997 a 2017 do estado de Minas Gerais

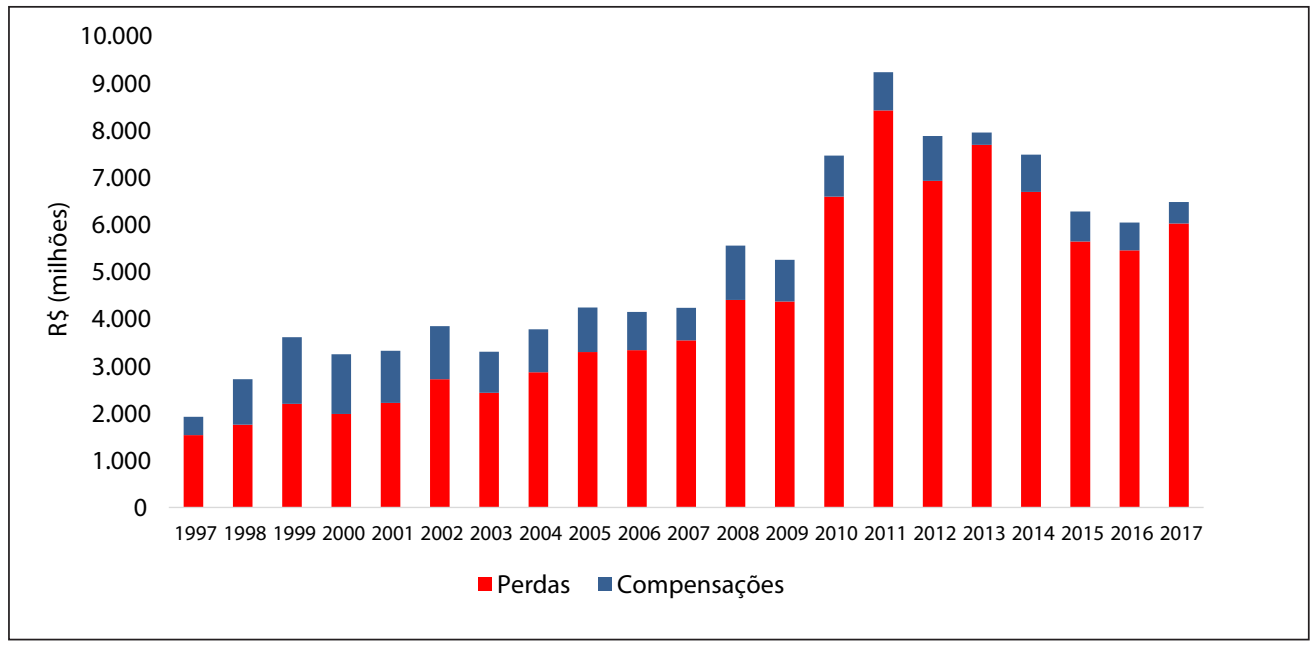

Fonte: elaboração própria a partir de dados da Fapespa (2016), do STN e do SNIPC/IBGE (2017)

"Valores atualizados pelo IPCA, dez/2017

Pode-se afirmar que um ano após o início da vigência da Lei 87/1996, o estado do Paraná (Gráfico 8) somou em perdas mais de 160 bilhões de reais em valores correntes, que caso ainda tivessem sido arrecadados pelo estado, representariam 5,3\% do total de ICMS arrecadado naquele mesmo ano. No caso de Minas Gerais, as perdas somaram pouco mais de 440 milhões de reais, que representariam 7,2 \% do ICMS recolhido em 1997. Com menores perdas àquele tempo, o Rio de Janeiro teve decréscimos no valor de 28 milhões de reais (valores correntes), o que significa o percentual de arrecadação de 0,55 \% (Gráfico 8).

Assim como o Paraná, o Rio de Janeiro só experimentou perdas nos anos posteriores à promulgação da lei e essas só vieram a transpor as compensações em 2001 (Gráfico 9), ano em que o petróleo já tinha tomado certa preponderância nas exportações do estado. Dado o crescimento da produção/exportação de petróleo no Brasil, essa unidade federativa acabou por se tornar a segunda colocada entre os estados que mais perderam com as renúncias fiscais em obediência à Lei Kandir. Contudo, os dados mostram a rapidez com que a Lei Kandir se tornou uma fonte de perdas ao estado, dado que suas perdas têm início relativamente recente dentro do contexto nacional. 
Gráfico 8 - Perdas brutas de arrecadação de ICMS desonerado pela Lei Kandir e valor das compensações financeiras de 1997 a 2017 do estado do Paraná

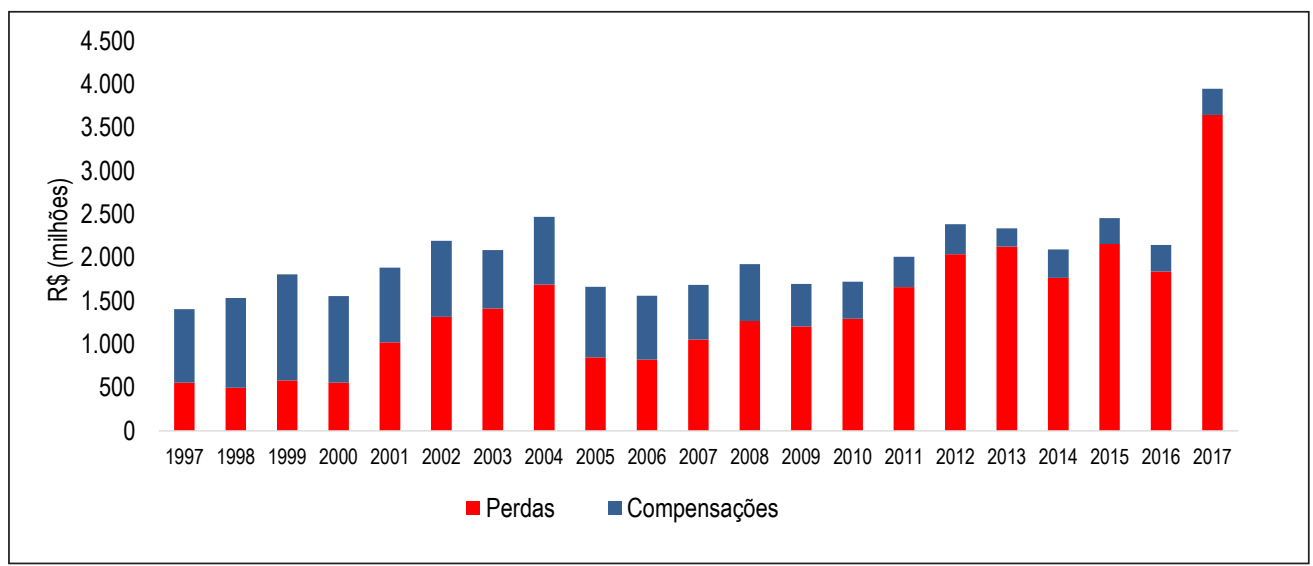

* Valores atualizados pelo IPCA, dez/2017

Fonte: elaboração própria a partir de dados da Fapespa (2016), do STN (2017) e do SNIPC/IBGE (2017)

Gráfico 9 - Perdas brutas de arrecadação de ICMS desonerado pela Lei Kandir e valor das compensações financeiras de 1997 a 2017 do estado do Rio de Janeiro

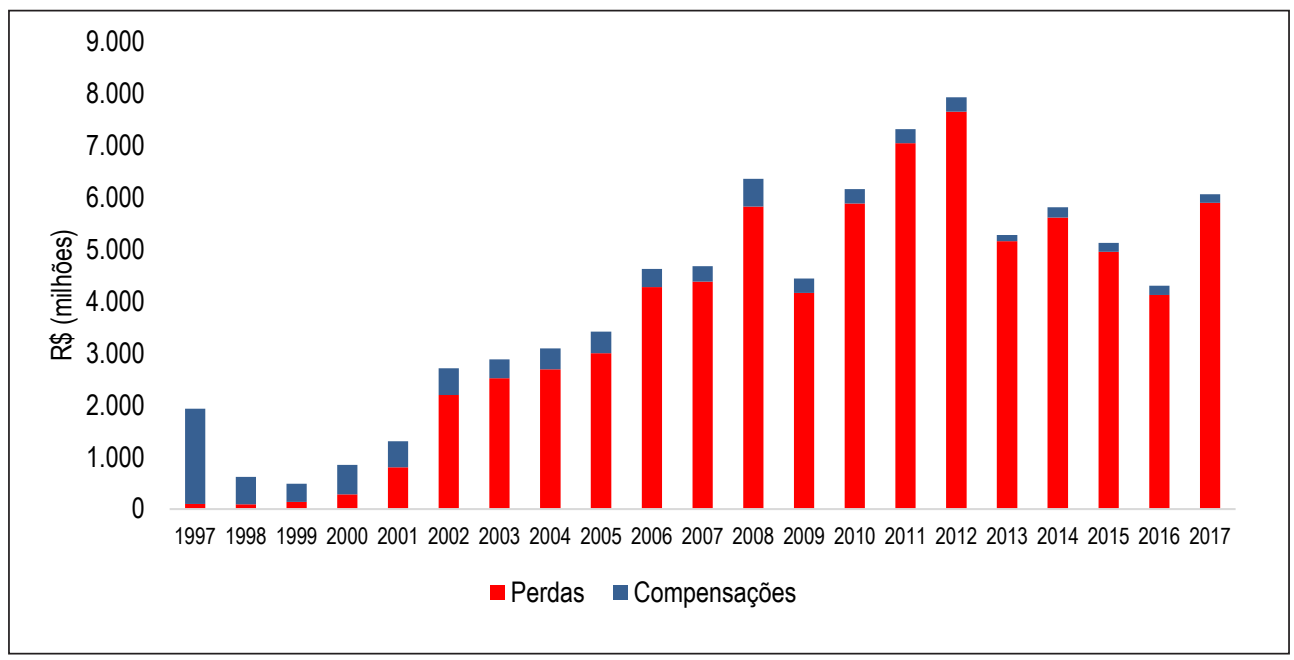

* Valores atualizados pelo IPCA, dez/2017

Fonte: elaboração própria a partir de dados da Fapespa (2016), do STN (2017) e do SNIPC/IBGE (2017)

\section{CONCLUSÕES}

A partir do apresentado pelo artigo, viu-se que a reprimarização da pauta de exportação brasileira é fenômeno que tem se acentuado nas últimas décadas, resultado de 
um claro processo de inserção aos fluxos econômicos e comerciais internacionais pela via da especialização em vantagens comparativas. A maior participação de bens primários e semielaborados no montante exportado pelo país reflete também uma preocupação com as dinâmicas territoriais em escala subnacional, notadamente das regiões produtoras desses bens e que apresentem grande dependência em relação a eles.

Nesse contexto, dá-se a análise de Minas Gerais, Rio de Janeiro e Paraná. Com base apenas nesses três estados, pode-se observar o quão preponderante foram as perdas com a Lei Kandir, principalmente para os estados que tinham sua base exportadora ancorada nos produtos desonerados. Ainda que o Governo Federal tenha criado mecanismos de compensações, estes não têm alcançado níveis que de fato cubram as perdas resultantes da desoneração.

Por fim, destaca-se que a busca por um regime federativo mais harmônico entre os entes federados demandará a reflexão sobre o papel cabido às escalas subnacionais nas estratégias de desenvolvimento.

\section{BIBLIOGRAFIA}

Arvate, Paulo Roberto e Biderman, Ciro (Org.) (2005). Economia do Setor Público no Brasil. Rio de Janeiro: Elsevier, 560p.

Brandão, Carlos (2016). As Ausências e Elos Faltantes das Análises Regionais no Brasil e a Proposição de uma Agenda de Pesquisas de Longo Prazo. Relatório Final de Pesquisa IPEA, 58p.

Carneiro, Ricardo (2012). Commodities, choques externos e crescimento: reflexões sobre a América Latina. Série Macroeconomia del Desarrollo. Cepal, Santiago, 46p.

Dall'acqua, Fernando Maida (2001). O impacto da Lei Kandir sobre a economia paulista. Em: Eaesp/FGV/NPP, Relatório de pesquisa, n. ${ }^{\circ}$ 22, p. 1-65.

Giambiagi, Fabio; Além, Ana Claudia (2011). Financias públicas: teoria e prática no Brasil. Rio de Janeiro: Elsevier, 576p.

Gorenstein, Silvia e Ortiz, Ricardo (2018). Natural resources and primary sector-dependent territories in Latin America. Em: Area Development and Policy, vol. 3, n. ${ }^{\circ}$ 1, p. 42-59.

Monteiro, Maria Carmina; Couto, André; Costa, Marcelo e Lemos, Renato (2017). Verbete Biográfico: Antônio Kandir. Em: FGV - CPDOC, 8p.

Monteiro Neto, Aristides e Silva, Raphael de O. (2018). Desconcentração territorial e reestruturação regressiva da indústria: o padrão brasileiro recente (1995-2015). Brasília: IPEA - DIRUR, $81 \mathrm{p}$.

Monteiro Neto, Aristides; Ismael, Ricardo; Romanatto, Eduiges; Matos, Elmer Nascimento; Fiori, Tomás Pinheiro e Birkner, Walter Marcos (2017). Federalismo e Relações Intergovernamentais: dinâmicas, impasses e consensos atuais. Rio de Janeiro: Ipea, 102p. 
Nonnenberg, Marcelo José B. (2018). Mudança estrutural e competitividade das exportações brasileiras: uma visão de longo prazo. Brasília - DF: Ipea, Texto para discussão n. ${ }^{\circ}$ 2377, 38p.

Ocampo, José A. (2012). La historia y los retos del desarrollo latinoamericano. Cepal, Ilpes, Santiago de Chile, 34p.

Piancastelli, Marcelo e Perobelli, Fernando (1996). ICMS: Evolução recente e Guerra Fiscal. Brasília - DF: Ipea, Texto para discussão n. ${ }^{\circ}$ 402, 58p.

Rezende, Fernando (2009). ICMS: Como era, o que mudou ao longo do tempo, perspectivas e novas mudanças. Brasília: Caderno Fórum Fiscal, n. ${ }^{\circ}$ 10, jun, 50p.

Riani, Flávio e Albuquerque, Célio Marcos Pontes de (2008). Lei Kandir e a Perda de Receita do estado de Minas Gerais. Em: Seminário de Economia Mineira, Diamantina. $13^{\circ}$ Seminário de Economia Mineira, $22 \mathrm{p}$.

Serra, José (1982). Ciclos e mudanças estruturais na Economia Brasileira do após-Guerra. Em: Revista de Economia Política, vol. 2/2, n. ${ }^{\circ}$ 6, 9p.

Silva, Robson D. (2013). Recursos Naturais não Renováveis e Desenvolvimento Regional: Apontamentos para o Caso Brasileiro. Em: Brandão, Carlos A. Território e Desenvolvimento: as múltiplas escalas entre o local e o global. Campinas: Editora da Unicamp, 238p.

Soares, Murilo Rodrigues da Cunha (2007). Lei Kandir: Breve Histórico. Brasília: Câmara dos Deputados, 15p.

Varsano, Ricardo (1998). A Guerra Fiscal do ICMS: Quem ganha e quem perde. Rio de Janeiro: Ipea, texto n. ${ }^{\circ}$ 500, $13 p$.

Vieira, Danilo Jorge (2013). Apontamentos sobre a Guerra Fiscal no Brasil. Em: Brandão, Carlos e Siqueira, Hipólita (2013). Pacto federativo nacional e desenvolvimento regional. São Paulo: Editora Fundação Perseu Abramo, p. 145-162.

\section{OUTRAS REFERÊNCIAS}

Câmara dos Deputados. Projeto de Lei Complementar 95, de 13 de maio de 1996. Projeto de Lei da futura Lei 87/1996, 10p.

Congresso Nacional. Constituição da República Federativa do Brasil, de 5 de outubro de 1988. Lei Maior do país, 134p.

Congresso Nacional. Emenda Constitucional 42 , de 19 de dezembro de 2003. Altera o sistema tributário nacional e dá outras providências, $6 \mathrm{p}$.

Congresso Nacional. Lei Complementar 102, de 11 de julho de 2000. Altera dispositivos da Lei 87/1996, 5p.

Congresso Nacional. Lei Complementar 115, de 26 de dezembro de 2002. Altera as leis complementares 87/1996 e 102/2000, 2p.

Congresso Nacional. Lei Complementar 65, de 15 de abril de 1991. Define, na forma da alínea $\mathrm{X}$ do art. 155 da $\mathrm{CF}$, os produtos semielaborados que podem ser tributados quando exportados, $2 \mathrm{p}$. 
Congresso Nacional. Lei Complementar 87, de 13 de setembro de 1996. Lei Kandir, que dispõe sobre operações relativas ao ICMS, 13p.

Congresso Nacional. Lei 10.966, de 9 de novembro de 2004. Autoriza a União a prestar auxílio financeiro aos Estados, Distrito Federal e aos Municípios, 2p.

Congresso Nacional. Medida Provisória 193, de 24 de junho de 2004. Autoriza a União a prestar auxílio aos Estados, Distrito Federal e aos Municípios para fomento às exportações, 2p.

Fapespa —Fundação Amazônica de Amparo a Estudos e Pesquisas — (2017). O impacto da lei Kandir na Arrecadação do ICMS dos estados no período 1997-2016: estimativa das perdas com as desonerações das exportações de Produtos Primários e Semielaborados. Nota Técnica, 59p.

IBGE —Instituto Brasileiro de Geografia e Estatísticas - (2015). Contas Nacionais n. 57. ISSN 1415-9813. 12p.

Ipeadata —Instituto de Pesquisa Econômica Aplicada - (2018). Base de dados macroeconômica.

MDIC —Ministério da Indústria, Comércio Exterior e Serviços- (2018). Balança comercial brasileira: acumulado do ano.

MDIC —Ministério da Indústria, Comércio Exterior e Serviços— (2018). Balança comercial brasileira: estados.

MDIC —Ministério da Indústria, Comércio Exterior e Serviços - (2018). Comex Vis: visualizações de comercio exterior.

Presidente da República. Decreto de lei 406, de 31 de dezembro de 1968. Estabelece normas gerais de direito financeiro, aplicáveis ao ICMS e outras providências, 12p.

RFB - Receita Federal do Brasil— (2016). Carga Tributária no Brasil — 2015: Análise por Tributo e Bases de Incidência. Brasília: Cetad 57p.

STN — Secretária do Tesouro Nacional, Ministério da Fazenda- (2014). Auxílio Financeiro para Fomento das Exportações (FEX), julho, 8p. 